\title{
CACNA1G wt Allele
}

National Cancer Institute

\section{Source}

National Cancer Institute. CACNA1G wt Allele. NCI Thesaurus. Code C105857.

Human CACNA1G wild-type allele is located in the vicinity of $17 q 22$ and is approximately $66 \mathrm{~kb}$ in length. This allele, which encodes voltage-dependent T-type calcium channel subunit alpha-1G protein, plays a role in both calcium transport and membrane depolarization. 